\title{
The photolysis of ortho-nitrophenols: a new gas phase source of HONO
}

\author{
Iustinian Bejan, ${ }^{a}$ Yasin Abd El Aal, ${ }^{a}$ Ian Barnes, ${ }^{a}$ Thorsten Benter, ${ }^{a}$ Birger Bohn, ${ }^{b}$ \\ Peter Wiesen $^{a}$ and Jörg Kleffmann*a
}

\author{
Received 22nd November 2005, Accepted 7th March 2006 \\ First published as an Advance Article on the web 20th March 2006 \\ DOI: $10.1039 / \mathbf{b 5 1 6 5 9 0 c}$
}

Formation of nitrous acid (HONO) in the gas phase has been observed for the first time in a flow tube photoreactor upon irradiation $(\lambda=300-500 \mathrm{~nm})$ of 2-nitrophenol and methyl substituted derivatives using a selective and sensitive instrument (LOPAP) for the detection of HONO.

Formation of $\mathrm{HONO}$ by heterogeneous $\mathrm{NO}_{2}$ photochemistry has been excluded, since production of $\mathrm{NO}_{2}$ under the experimental conditions is negligible. Variation of the surface to volume ratio and the nitrophenol concentration showed that the photolysis occurred in the gas phase indicating that HONO formation is initiated by intramolecular hydrogen transfer from the phenolic $\mathrm{OH}$ group to the nitro group. From the measured linear dependence of the HONO formation rate on the reactant's concentration and photolysis light intensity, a non-negligible new HONO source is proposed for the urban atmosphere during the day. Unexpectedly high HONO mixing ratios have been observed recently in several field campaigns during the day. It is proposed that the photolysis of aromatic compounds containing the ortho-nitrophenol entity could help to explain, at least in part, this high contribution of HONO to the oxidation capacity of the urban atmosphere.

\section{Introduction}

Aromatic hydrocarbons are an important class of volatile organic compounds (VOCs) that are emitted into the troposphere as a result of anthropogenic activities. ${ }^{1}$ These hydrocarbons contribute significantly to the chemistry of urban $\operatorname{air}^{2,3}$ with an estimated contribution to the total anthropogenic non-methane VOC emissions of up to $25 \%{ }^{1}$ In the atmosphere, aromatic hydrocarbons react mainly with $\mathrm{OH}$ radicals during the day. In addition, reactions with $\mathrm{O}_{3}$ and $\mathrm{NO}_{3}$ (mainly during the night) can contribute to their degradation. Based on mechanisms proposed for the atmospheric degradation of aromatic hydrocarbons, it is estimated that this class of VOC could account for up to $30 \%$ of the photooxidant formation in urban areas. ${ }^{4,5}$ Therefore, aromatic hydrocarbons are a very important class of VOCs emitted into the urban atmosphere. Besides the formation of photooxidants, aromatic hydrocarbons are also believed to make a significant contribution to secondary organic aerosol (SOA) formation in urban areas. $^{6-8}$

Among the diverse types of aromatic hydrocarbons, nitrophenols are of particular interest. The initial impetus to study the atmospheric behaviour of nitrophenols stems from the hypothesis that because of their phytotoxic properties they could be a contributing factor to forest decline. ${ }^{9,10}$ Nitrophenols are directly emitted into the atmosphere and can be formed in situ by secondary photochemical processes. Direct sources of nitrophenols into the atmosphere are the combustion of coal and wood, and the manufacture of phenol-

\footnotetext{
${ }^{a}$ Physikalische Chemie/FB C, Bergische Universität Wuppertal, 42097 Wuppertal,Germany.E-mail:kleffman@uni-wuppertal.de

${ }^{b}$ Institut für Chemie und Dynamik der Geosphäre II: Troposphäre,

Forschungszentrum Jülich, 52425 Jülich, Germany
}

formaldehyde resins, explosives, dyes and pharmaceuticals. ${ }^{11}$ Oxidation of phenols and cresols by $\mathrm{OH} / \mathrm{NO}_{x}$ and $\mathrm{NO}_{3}$ radicals are mainly responsible for the secondary formation of different nitrophenols. ${ }^{12-14}$ Nitrophenols have been detected in ambient air, ${ }^{11,15-17}$ clouds, ${ }^{18}$ soil, ${ }^{19}$ fog $^{20}$ and snow. ${ }^{21}$

In contrast to the liquid phase, ${ }^{11,22-24}$ the photochemistry of nitrophenols in the gas phase has, to the best of our knowledge, received virtually no attention. Nitrophenols strongly absorb in the atmospherically relevant UV range 300-400 $\mathrm{nm},{ }^{11,22,23}$ corresponding to the $\mathrm{S}_{1} \leftarrow \mathrm{S}_{0}$ transition as reported for the liquid phase. ${ }^{22}$ Thus, the photochemistry of nitrophenols might be of importance for the atmosphere. The formation of nitrous acid (HONO)/nitrite has been observed during the photolysis of nitrophenols in the liquid phase $\mathrm{e}^{22-24}$ or in ice $^{25}$ where its formation is attributed to intramolecular interactions and solvent reactions.

The properties of 2-nitrophenol $\left(\mathrm{OH}\right.$ and $\mathrm{NO}_{2}$ groups in ortho position to each other, structure I) and its methylated analogues, i.e. melting point, vapour pressure, infrared absorption spectra, are significantly different compared to those of other nitrophenols. This difference is caused by strong intramolecular hydrogen bonding as shown in structure $\mathrm{II}^{26-33}$

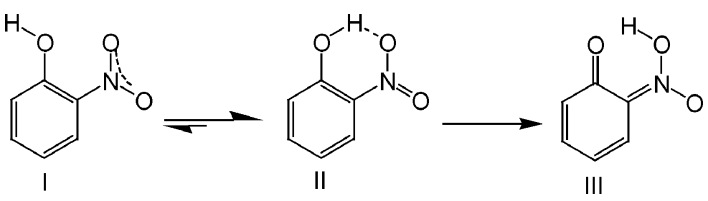

This hydrogen bond can be considered the first step in a proton transfer process, leading to a nitronic acid structure III. ${ }^{31,34}$ For the nitronic acid structure III arising from nitrobenzene, dissociation leading to the formation of HONO has been predicted for the gas phase on the basis of theoretical 
calculations. ${ }^{35}$ Thus, photo-dissociation of 2-nitrophenol and its methylated derivatives via structure III and formation of HONO in the gas phase might also be possible, as observed in the liquid phase. ${ }^{22-24}$ To date, no observations of nitrous acid formation from the gas phase photolysis of nitrophenols have been reported in the literature.

Nitrous acid is of considerable atmospheric interest since the photolysis

$$
\mathrm{HONO}+h \nu \rightarrow \mathrm{NO}+\mathrm{OH}
$$

leads to the formation of $\mathrm{OH}$ radicals, the key atmospheric oxidant in the degradation of most air pollutants and a crucial intermediate in the formation of photochemical smog in the troposphere. Previous field and modelling studies have demonstrated that HONO photolysis contributes considerably to the daily $\mathrm{OH}$ production with an integrated contribution of up to $60 \%{ }^{36-43}$ While the night time formation of HONO in the atmosphere is reasonably well explained by direct emissions and different heterogeneous conversion processes of $\mathrm{NO}_{2}{ }^{44-46}$ on ground surfaces, ${ }^{42}$ recent sensitive measurements have shown unexpectedly high HONO concentrations during the daytime. $^{36,38,41,43,47}$ The measured HONO levels were significantly higher than the values predicted on the basis of the available knowledge about daytime sources and sinks of HONO. The experiments revealed the existence of a strong daytime source of HONO up to 60 times higher than the night time sources ${ }^{43}$ and contributing up to $60 \%$ to the direct $\mathrm{OH}$ radical sources, ${ }^{48}$ which was suggested to arise from the photolysis of adsorbed $\mathrm{HNO}_{3} /$ nitrate $^{38,47,49-51}$ or by heterogeneous photochemistry of $\mathrm{NO}_{2}$ on organic substrates. ${ }^{52-54}$

Recent work in our laboratory on different aspects of aromatic hydrocarbon photooxidation processes performed in the presence of OH-radical scavengers has revealed that $\mathrm{OH}$ radicals are generated during the photolysis of nitrophenols. Since the formation of HONO is known for the photolysis of nitrophenols in the liquid phase and since the identification of daytime sources of HONO is of paramount importance for an understanding of the high daytime concentrations recently observed in the atmosphere, investigations have been performed to study HONO formation in the gas phase photolysis of different nitrophenols.

\section{Experimental}

The photolysis of nitrophenols was studied in the glass flow reactor shown in Fig. 1. The following nitrophenols as provided by the manufacturer were investigated: 2-nitro-1-hydroxybenzene (2-nitrophenol: 2NP, Aldrich, 98\% purity), 3-methyl-2-nitro-1-hydroxybenzene (3-methyl-2-nitrophenol: 3M2NP, Fluka 98\% GC purity), 4-methyl-2-nitro-1-hydroxybenzene (4-methyl-2-nitrophenol: 4M2NP, Aldrich, 99\% purity) and 3-methyl-6-nitro-1-hydroxybenzene (5-methyl2-nitrophenol: 5M2NP, Aldrich, 97\% purity). A gas phase mixture containing a nitrophenol was generated by flushing $2.5 \mathrm{~L} \mathrm{~min}^{-1}$ pure synthetic air (flow controller: Bronkhorst, $2.5 \mathrm{~L} \mathrm{~min}^{-1}$ ) over a solid or liquid sample of the nitrophenol, which was immersed in a temperature regulated water bath. The vapour pressure of the nitrophenol in the gas phase was adjusted by variation of the temperature of the water bath.

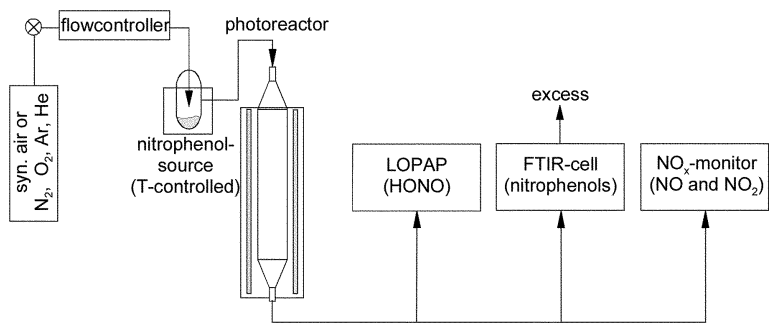

Fig. 1 Experimental set-up used for the photolysis of the nitrophenols.

For some experiments with 3M2NP the influence of the buffer gas on the HONO formation rate was investigated by using calibrated flows of $\mathrm{N}_{2}(99.999 \%, 99.9999 \%), \mathrm{O}_{2}(99.999 \%)$, $\operatorname{Ar}(99.999 \%)$ or He $(99.9999 \%)$ in place of synthetic air.

The gas containing the nitrophenol was passed through the photoreactor, for which either a $9 \mathrm{~mm}$ id glass tube (length 46 $\mathrm{cm}, S / V=4.4 \mathrm{~cm}^{-1}$, borosilicate glass) or a cylindrical glass flow tube (length $80 \mathrm{~cm}, 50 \mathrm{~mm}$ id, conic entrance and exit junctions, $S / V=0.75 \mathrm{~cm}^{-1}$, borosilicate glass) was used. The photoreactors were placed in an aluminium housing, in which six UV/VIS lamps (Phillips TL/05, $20 \mathrm{~W}, 300-500 \mathrm{~nm}, \lambda_{\max }=$ $370 \mathrm{~nm}$, length $=57 \mathrm{~cm}$ ) were installed symmetrically around the photoreactor and could be operated individually. A fan installed in the aluminium housing prevented strong heating of the photoreactor. The temperature increase over ambient temperature $(298 \pm 5 \mathrm{~K})$ during irradiation was 3-4 K.

Spectral actinic flux measurements inside a replicate reactor were made to characterise the spectral output of the lamps. A calibrated spectroradiometer ${ }^{55}$ with a small $2 \pi$ sr actinic flux Teflon receptor and a quartz fibre was used for the measurements inside the flow reactor. Except for a few sharp peaks, the lamp spectra consist of a broad continuum with a maximum around $370 \mathrm{~nm}$ and a $70 \mathrm{~nm}$ full width at half maximum decreasing more strongly towards shorter wavelengths.

Typically, the effluent from the photoreactor was analysed for $\mathrm{HONO}$, nitrophenols and, in a few experiments, for $\mathrm{NO}_{2}$. Nitrous acid was measured with a newly developed, highly sensitive instrument (LOPAP), which is described in detail elsewhere ${ }^{56,57}$ Briefly, HONO is sampled in a stripping coil by a fast chemical reaction and converted into an azo dye, which is photometrically detected by long path absorption in light conducting Teflon tubes. The two-channel set-up of the instrument corrects for interferences ${ }^{57}$ including those caused by mixtures of $\mathrm{NO}_{2}$ and semi-volatile diesel exhaust components. ${ }^{58}$ In recent intercomparison campaigns with the DOAS technique in the field and in a smog chamber, excellent agreement was also obtained for daytime conditions. ${ }^{59}$ For the experimental conditions applied in the present study, the instrument had a detection limit of 5 pptv for a time resolution of $2.5 \mathrm{~min}$.

The concentration of the nitrophenol was determined using a FTIR spectrometer coupled to a $10 \mathrm{~L}$ White type multiple reflection cell operated at a total optical path length of $32.8 \mathrm{~m}$. The cell was connected to the exit of the photoreactor (Fig. 1). IR spectra were recorded at a spectral resolution of $1 \mathrm{~cm}^{-1}$ using a Nicolet NEXUS FT-IR spectrometer equipped with a MCT detector. Spectra were recorded by co-adding 128 scans 
per spectrum over a time period of 2 min while sampling continuously during the experiments. Cross sections as reported by Olariu, ${ }^{60}$ were used at the following spectral wavenumbers to calculate the nitrophenol concentrations: 1627 and $1343 \mathrm{~cm}^{-1}$ for 2-nitrophenol; 1609 and $1351 \mathrm{~cm}^{-1}$ for 3-methyl-2-nitrophenol; 1639, 1335 and $1191 \mathrm{~cm}^{-1}$ for 4-methyl-2-nitrophenol; 1634, 1603, 1335 and $1203 \mathrm{~cm}^{-1}$ for 5-methyl-2-nitrophenol.

For some experiments, the $\mathrm{NO}_{2}$ dependence of the photolytic HONO formation rate and the upper limit of the $\mathrm{NO}_{2}$ formation rate during the photolysis of pure nitrophenols were determined with a Luminol $\mathrm{NO}_{2}$ monitor (Unisearch, LMA$3 \mathrm{D})$. The instrument was calibrated with $\mathrm{NO}_{2}$ mixing ratios of 0-30 ppbv containing nitrophenol mixing ratios comparable to the photolysis experiments, since ppmv levels of nitrophenols led to a significant reduction of the sensitivity of the instrument. $\mathrm{NO}_{2}$ was obtained from Messer Griesheim as a 10 ppmv premix gas balanced with $\mathrm{N}_{2}$. The error in the $\mathrm{NO}_{2}$ concentration was calculated from the accuracy of the $\mathrm{NO}_{2}$ calibration mixture, specified by Messer Griesheim, and the statistical errors of the calibration curve.

Photolysis of $\mathrm{NO}_{2}\left(\mathrm{NO}_{2}+h \nu \rightarrow \mathrm{NO}+\mathrm{O}\right)$ was studied as a photochemical reference reaction within the reactor. A $\mathrm{NO}_{x}$ $\left(\mathrm{NO}+\mathrm{NO}_{2}\right)$ chemiluminescence analyser (Eco-Physics: $\mathrm{AL}$ 770 ppt) with a photolytic converter (Eco Physics: PLC 760) was used to measure the decrease of the $\mathrm{NO}_{2}$ concentration upon irradiation at various photolysis times and different initial $\mathrm{NO}_{2}$ concentrations. The photochemical conversion rate of $\mathrm{NO}_{2}$ is quantified by the photolysis frequency $J\left(\mathrm{NO}_{2}\right)$

$$
J\left(\mathrm{NO}_{2}\right)=-1 /\left[\mathrm{NO}_{2}\right] \times \Delta\left[\mathrm{NO}_{2}\right] / \Delta t
$$

where $J\left(\mathrm{NO}_{2}\right)$ was calculated numerically incorporating the chemistry of the Leighton equilibrium ${ }^{61}$ and recommended rate constants. ${ }^{62}$ For all six lamps, a value for $J\left(\mathrm{NO}_{2}\right)$ of 0.018 $\mathrm{s}^{-1}$ was determined inside the photoreactor. This result is in good agreement with the $J\left(\mathrm{NO}_{2}\right)$ of $0.016 \mathrm{~s}^{-1}$ calculated from the measured actinic flux spectra taking into account the reactor geometry and molecular data of $\mathrm{NO}_{2}$, i.e. absorption cross sections and quantum yields. ${ }^{55}$ The Eco Physics instrument could not be used for the experiments with the nitrophenols, since the $\mathrm{NO}_{x}$ concentration measured by the instrument was significantly lower than the NO concentration in the presence of ppmv levels of nitrophenols, due to photochemical reactions leading to $\mathrm{NO}_{x}$ losses in the photolytic converter.

\section{Results}

When mixtures of nitrophenols at ppmv levels were irradiated in the photoreactor an instantaneous formation of HONO at ppbv levels was observed in the gas phase in all cases. HONO formation was not observed in the dark (see Fig. 2). No significant change in the nitrophenol concentrations upon photolysis could be established by the FTIR measurements. This, however, is due to the low precision of the FTIR measurements. The upper limit of the loss of nitrophenols during the irradiation was $<50$ ppbv for all the experiments. When the photoreactor was not cleaned before the experiments, HONO formation was also observed during the irradiation of the photoreactor flushed with synthetic air only.

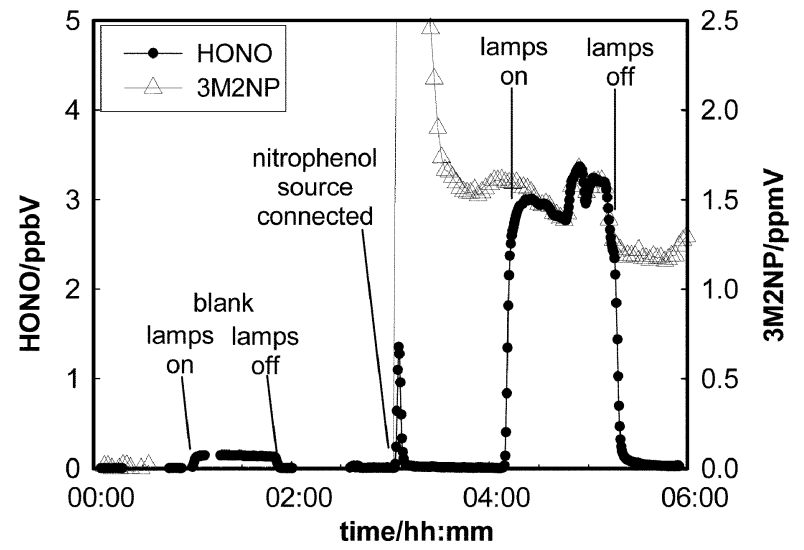

Fig. 2 HONO formation during the irradiation of the empty reactor flushed with synthetic air (blank) and during the irradiation of $3 \mathrm{M} 2 \mathrm{NP}$ in synthetic air $\left(J\left(\mathrm{NO}_{2}\right)=0.018 \mathrm{~s}^{-1}, t_{\text {reac }}=26.7 \mathrm{~s}\right)$.

However, this blank formation was normally significantly lower than the HONO formation observed in the presence of the nitrophenols (see Fig. 2) and was taken into consideration in the evaluation of the data.

The stability of the nitrophenol source varied significantly during the experiments, however, the HONO concentration during irradiation followed perfectly the fluctuations in the nitrophenol concentration (see Fig. 2). A linear correlation between the HONO and nitrophenol concentration was observed in separate experiments for all of the nitrophenols investigated. An example of this linear correlation is shown in Fig. 3 for $3 \mathrm{M} 2 \mathrm{NP}$. HONO loss by photolysis within the reactor is estimated to be $<5 \%$.

When two photoreactors with significantly different surface to volume ratios $(S / V)$ and volumes were used, the HONO concentration in the effluent differed significantly between the reactors. The ratio of the HONO yield per ppmv of $3 \mathrm{M} 2 \mathrm{NP}$ used was a factor of 40 smaller for the $9 \mathrm{~mm}$ id photoreactor compared to the $50 \mathrm{~mm}$ id photoreactor (see slopes in Fig. 3). The 40 times lower HONO yield perfectly matches the ratio of the photolysis time of the gas phase in both photoreactors, for

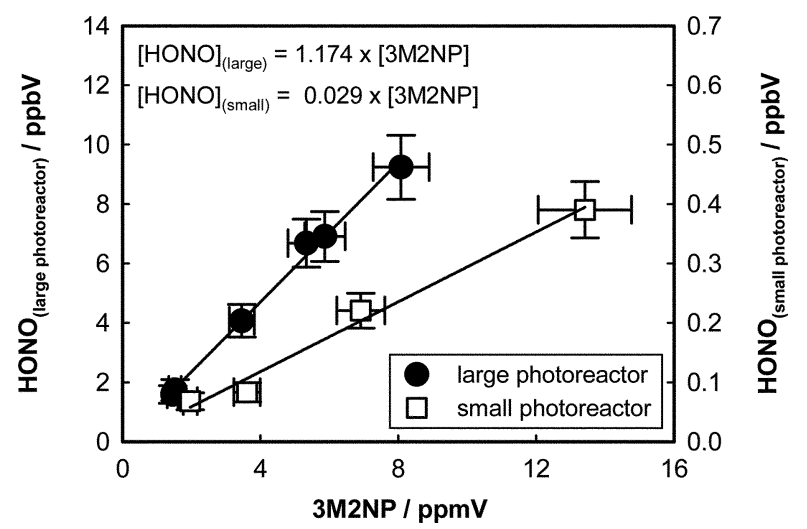

Fig. 3 HONO formation as a function of the concentration of $3 \mathrm{M} 2 \mathrm{NP}$ in two different photoreactors $\left(S / V_{\text {(large) }}=0.75 \mathrm{~cm}^{-1}\right.$, $\left.t_{\text {reac(large) }}=26.7 \mathrm{~s}, S / V_{\text {(small) }}=4.44 \mathrm{~cm}^{-1}, t_{\text {reac(small })}=0.64 \mathrm{~s}\right)$. The ratio of the slopes of 40 matches the ratio of the photolysis times of 41 very well. 


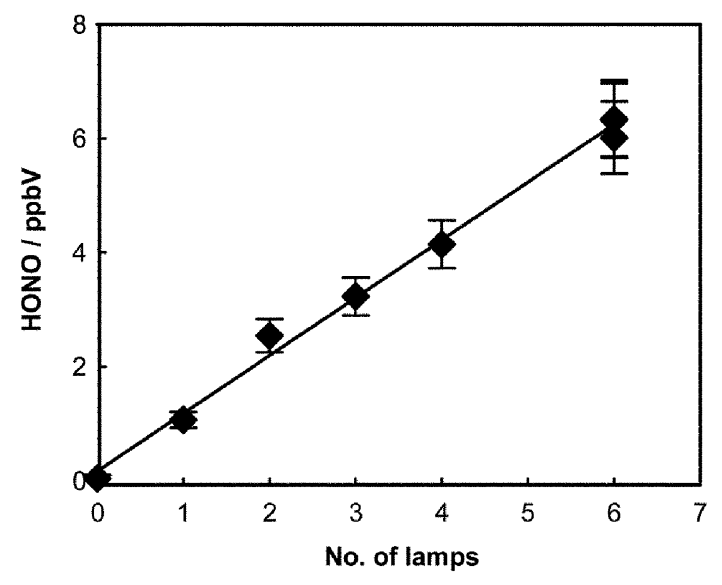

Fig. 4 HONO formation during the photolysis of $3 \mathrm{M} 2 \mathrm{NP}$ in the large photoreactor as a function of the number of operating lamps $\left(t_{\text {reac(large })}=26.7 \mathrm{~s}\right)$.

which a value of 41 was calculated. In contrast, the ratio of the product $S / V \times t_{\text {reac }}$ changed by only a factor of seven.

The influence of the light intensity on the HONO formation rate during the photolysis of $3 \mathrm{M} 2 \mathrm{NP}$ was also studied for the large photoreactor by variation of the number of lamps switched on. A linear correlation between the HONO formation and the number of lamps switched on was observed (see Fig. 4).

Since there is the possibility of $\mathrm{NO}_{2}$ formation during the irradiation of the nitrophenols and since $\mathrm{NO}_{2}$ can be photochemically converted into HONO on organic surfaces, ${ }^{52-54}$ the influence of $\mathrm{NO}_{2}$ on the HONO formation rate was studied for $3 \mathrm{M} 2 \mathrm{NP}$. A significant increase in the HONO formation was observed when $\mathrm{NO}_{2}$ was added (see Fig. 5). The additional HONO formation was found to be non-linearly correlated with the initial $\mathrm{NO}_{2}$ concentration. This is similar to what has been observed in recent studies on organic surfaces. ${ }^{52-54}$

However, when the $\mathrm{NO}_{2}$ formation was measured during the irradiation of pure $3 \mathrm{M} 2 \mathrm{NP}$ mixtures $(2.5 \mathrm{ppmv})$ only an upper limit of $\leq 0.14 \mathrm{ppbv} \mathrm{NO}_{2}$ could be estimated. The photolysis of any $\mathrm{NO}_{2}$ which might have been formed in the

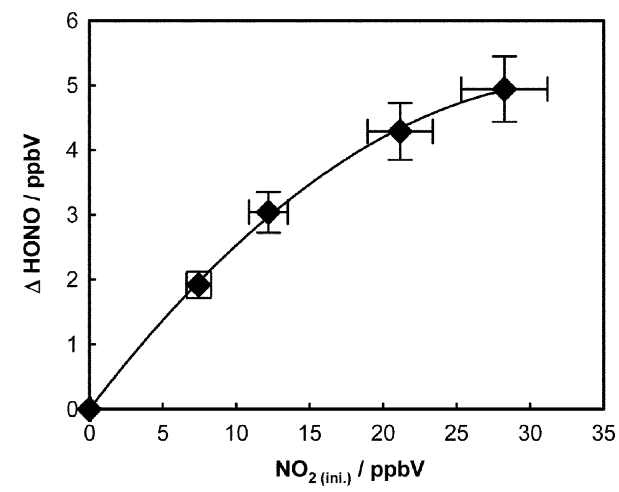

Fig. 5 Additional HONO formation by $\mathrm{NO}_{2}$ photochemistry ${ }^{52-54}$ during the irradiation of $3 \mathrm{M} 2 \mathrm{NP}(2.5 \mathrm{ppmv})$ in the large photoreactor using 6 lamps as a function of the initial $\mathrm{NO}_{2}$ concentration $\left(t_{\text {reac }}=\right.$ $\left.26.7 \mathrm{~s}, J\left(\mathrm{NO}_{2}\right)=0.018 \mathrm{~s}^{-1}\right)$. The photolytic HONO formation in the absence of $\mathrm{NO}_{2}$ was $\sim 3$ ppbv.

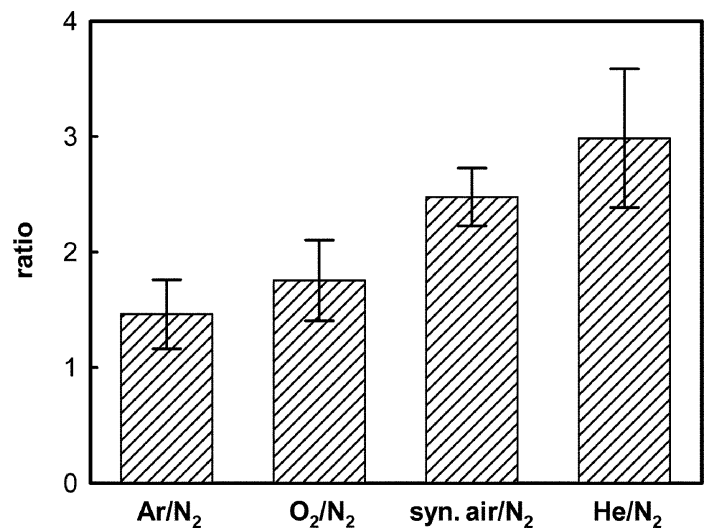

Fig. 6 Ratio of the HONO formation during the irradiation of $3 \mathrm{M} 2 \mathrm{NP}$ in a certain buffer gas to the formation in pure nitrogen normalized to the same concentration of $3 \mathrm{M} 2 \mathrm{NP}$.

photoreactor was taken into consideration for the calculation of this upper limit. Thus, these observations support the idea that only a small fraction of the observed HONO yield during the irradiation of pure nitrophenol mixtures can be explained by mechanisms involving $\mathrm{NO}_{2}$.

The influence of the buffer gas on the HONO formation rate was also investigated for the photolysis of 3M2NP. As can be clearly seen in Fig. 6, the nature of the buffer gas had a significant impact on the HONO formation. Compared to pure nitrogen $(99.999 \%$ or $99.9999 \%)$, the HONO yield increased by factors of $1.5,1.8,2.5$ and 3.0 in $\mathrm{Ar}, \mathrm{O}_{2}$, synthetic air and $\mathrm{He}$, respectively.

To test whether other nitrophenols are also potential sources of HONO during irradiation, HONO formation was studied for the photolysis of $2 \mathrm{NP}, 4 \mathrm{M} 2 \mathrm{NP}$ and $5 \mathrm{M} 2 \mathrm{NP}$ as a function of the concentration of the nitrophenols in synthetic air. For all compounds a linear dependency between HONO formation and the nitrophenol concentration was observed. As for the $\mathrm{NO}_{2}$ photolysis, formation of HONO from the different nitrophenols can be quantified by photolysis frequencies,

$J($ nitrophenol $\rightarrow \mathrm{HONO})=1 /[$ nitrophenol $] \times \Delta[\mathrm{HONO}] / \Delta t$.

The results are listed in Table 1. From the measured photolysis frequency of $3 \mathrm{M} 2 \mathrm{NP}$ a quantum yield $\phi(3 \mathrm{M} 2 \mathrm{NP} \rightarrow \mathrm{HONO})$ has been estimated under the assumption that this quantity is independent of wavelength. A value of $\phi(3 \mathrm{M} 2 \mathrm{NP} \rightarrow \mathrm{HONO})$ $\approx 1.5 \times 10^{-4}$ was calculated based on the actinic flux spectrum from the reactor and an absorption spectrum of 3M2NP obtained in liquid dichloromethane. Since the absorption cross section of $3 \mathrm{M} 2 \mathrm{NP}$ is unknown for the gas phase, it was assumed that the cross sections are similar for the gas and liquid phases.

For further verification of the mechanism, the photolysis of different 3- and 4-nitrophenols was attempted. However, because of the much lower vapour pressures of these compounds they could not be detected by FTIR, i.e. the vapour pressure at the temperature of the experimental set-up, i.e. room temperature, was much lower than the detection limit of the FTIR. 
Table 1 Photolysis frequency $J$ (nitrophenol $\rightarrow$ HONO) of HONO formation from different nitrophenols in the photoreactor under conditions with $J\left(\mathrm{NO}_{2}\right)=0.018 \mathrm{~s}^{-1}$ in synthetic air (errors: $2 \sigma$ )

\begin{tabular}{ll}
\hline Compound & $J($ nitrophenol $\rightarrow$ HONO $) / 10^{-5} \mathrm{~s}^{-1}$ \\
\hline $3 \mathrm{M} 2 \mathrm{NP}$ & $4.4 \pm 0.3$ \\
2NP & $2.9 \pm 0.6$ \\
$5 \mathrm{M} 2 \mathrm{NP}$ & $2.4 \pm 0.3$ \\
$4 \mathrm{M} 2 \mathrm{NP}$ & $1.1 \pm 0.1$ \\
\hline
\end{tabular}

\section{Discussion}

As shown in the Results section, the instantaneous HONO formation observed during the photolysis of several nitrophenols was linearly correlated with the light intensity in the photoreactor ( $c f$. Fig. 4), the concentration of the nitrophenols (cf. Fig. 3), and the photolysis time. However, the HONO formation was found to be independent of the $S / V$ ratio of the reactor, see Fig. 3. These observations all support the idea that HONO is being formed by a gas phase process. In the case of a heterogeneous reaction a dependence on $S / V$ would be expected. In addition, the perfect correlation of the HONO formation with the concentration of the nitrophenols, even for rapid concentration changes ( $c f$. Fig. 2), would not be expected for a surface process, where adsorption of the nitrophenols on the surface would lead to a measurable delay between the nitrophenol concentration changes and the HONO concentration.

Due to the low estimated quantum yield of $\sim 10^{-4}$ and purities of the different nitrophenols of only $97-99 \%$, HONO formation might also result from the photolysis of nitrogen containing impurities with a two orders of magnitude higher photolysis frequency. However, a linear concentration dependency was observed for all nitrophenols investigated (see Fig. 3 ). Since the concentration was varied by the temperature of the nitrophenol source, impurities can only explain the observed HONO formation if the temperature dependencies of the vapour pressures of the hypothetical impurities are similar to those of the different nitrophenols investigated. In addition, during the experiments the physical state of the samples changed between liquid and solid, depending on the temperature of the nitrophenol source, without affecting the HONO yield. In experiments in which 3M2NP with a higher purity $(99 \%$ instead of $98 \%)$ was used, no effect on the photolysis frequency $J$ (nitrophenol $\rightarrow$ HONO) was observed. A further indication that impurities are unimportant is given by the time dependence of the HONO formation during the blank experiments (see Fig. 2). This HONO formation was attributed to the photolysis of adsorbed nitrophenols on the walls, since in blank experiments, in which the photoreactor was cleaned, significantly lower HONO formation was observed. If impurities of $\sim 2 \%$ caused the HONO formation in the experiment with $3 \mathrm{M} 2 \mathrm{NP}$ shown in Fig. 2, the photolysis frequency of the impurities should have been $\sim 2 \times 10^{-3} \mathrm{~s}^{-1}$ (50 times the value for $3 \mathrm{M} 2 \mathrm{NP}$, see Table 1) leading to a lifetime of only $\sim 8 \mathrm{~min}$ for the impurities on the reactor walls. During the blank experiment shown in Fig. 2 the reactor was irradiated for $45 \mathrm{~min}$, which would thus result in an almost complete destruction of the impurities. However, the HONO formation only decreased from 0.15 to 0.13 ppbv (see Fig. 2), which is attributed to the decrease of the amount of adsorbed 3M2NP by desorption from the walls. In conclusion, HONO formation by the photolysis of impurities is very unlikely.

Recently, photolytic HONO formation was observed during the heterogeneous reaction of $\mathrm{NO}_{2}$ with phenolic hydrocarbons. ${ }^{52-54}$ This was also observed in the present study when $\mathrm{NO}_{2}$ was added to the nitrophenols under irradiation (see Fig. 5). However, in the present investigation, during the photolysis of pure nitrophenol-bath gas mixtures no $\mathrm{NO}_{2}$ formation was observed. Thus, from the upper limit of the $\mathrm{NO}_{2}$ yield of $\leq 0.14$ ppbv for a concentration of $3 \mathrm{M} 2 \mathrm{NP}$ of $2.5 \mathrm{ppmv}$ in the large photoreactor, and from the observed $\mathrm{NO}_{2}$ dependence in the case of $3 \mathrm{M} 2 \mathrm{NP}$ ( $c f$. Fig. 5) the contribution of mechanisms involving $\mathrm{NO}_{2}$ are estimated to be $\leq 3 \%$. Accordingly, the contribution to the formation of $\mathrm{HONO}$ by photolytic $\mathrm{NO}_{2}$ reactions ${ }^{52-54}$ during the photolysis of pure nitrophenols will be negligible. This conclusion is also supported by the gas phase nature of the process observed (see above). In contrast, for the photolytic $\mathrm{HONO}$ formation by $\mathrm{NO}_{2}$ reactions in the presence of phenolic compounds, a surface process has been proposed. $^{52-54}$

The linear dependence of the HONO formation on the concentration of the nitrophenols (see Fig. 3) also excludes an intermolecular reaction between two nitrophenol molecules, for which a quadratic concentration dependency would be expected. Instead, an elimination of HONO from the nitronic acid structure III, formed by photoexcitation of structure II of 2-nitrophenol, is proposed. In the study of Chen et al., ${ }^{31}$ structure III was proposed as a thermal decomposition product of 2-nitrophenol and it appears to be feasible that it is also formed by photoexcitation. In addition, abstraction of HONO was calculated to be energetically possible from a similar nitronic acid structure III of nitrobenzene, ${ }^{35}$ and might also explain the HONO formation in the gas phase observed in the present study for the photolysis of nitrophenols. HONO formation was also observed during the photolysis of 2-nitrophenol in the liquid phase $\mathrm{e}^{22-24}$ and was explained, at least in part, by the elimination of HONO leading to an organic biradical. ${ }^{23}$

To obtain further insight into the mechanism leading to HONO formation upon photolysis, the influence of the buffer gas was studied. From the different experiments in the absence of oxygen the following trend in the HONO yield was observed: $\operatorname{HONO}(\mathrm{He})>\operatorname{HONO}(\mathrm{Ar})>\operatorname{HONO}\left(\mathrm{N}_{2}\right)$ (see Fig. 6). From this observation it is concluded that HONO formation is caused, at least in part, by a sequence of reactions involving a photoinduced intramolecular $\mathrm{H}$ atom transfer to form a primary excited state III**, followed by energy transfer to form an excited state, structure III*, with subsequent elimination of HONO, i.e. reactions (a), (c) and (d) in mechanism (3). To explain the observed buffer gas dependency on the HONO yield it is proposed that the excited state III** can be additionally quenched by the buffer gas, the effectiveness of which will depend on the nature of the gas being used, see reaction (b). For the liquid phase, the formation of a biradical leading to the formation of a ketene was proposed to explain HONO formation during the irradiation of 2-nitrophenols ${ }^{23}$ and might also be a co-product of HONO during the gas phase photolysis, see reaction (d) in mechanism (3). 


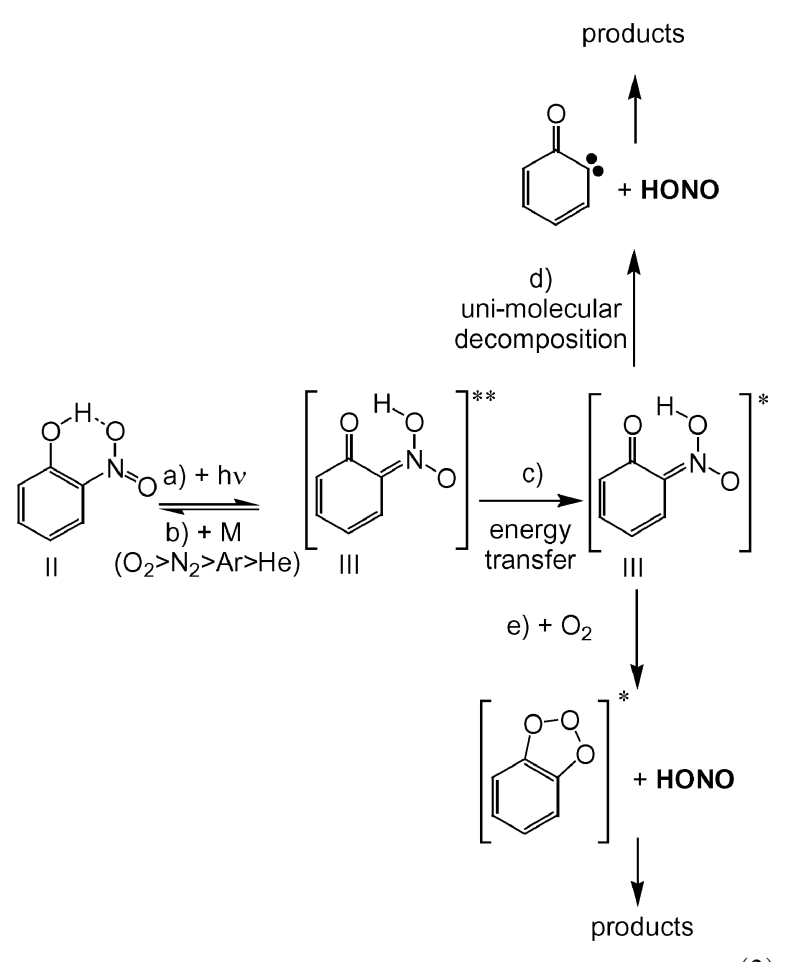

(3)

The proposed reactions (a)-(d) cannot, however, explain the observations in the presence of oxygen, for which a similar or even lower HONO formation compared to nitrogen would be expected, since oxygen is known to be an efficient quencher. However, $\mathrm{O}_{2}$ can potentially serve as both a third body collision partner in termolecular reactions and a reactant in bimolecular steps, depending on the electronic structure of the reactants and products. ${ }^{61}$ In the present experiments, the HONO yields in synthetic air and pure oxygen were significantly higher than that obtained in pure nitrogen ( $c f$. Fig. 6). Thus, in order to explain this anomaly, a further reaction is proposed, in which HONO is formed in a reaction of oxygen with the excited state III*, i.e. reaction (e) in mechanism (3). With this additional process the decrease in HONO formation observed on switching from synthetic air to pure oxygen (see Fig. 6) can also be explained. For relatively low oxygen concentrations (synthetic air) the concentrations of III** and III* are still high and reaction (e) will lead to a high HONO yield. When the oxygen concentration is further increased $\left(100 \% \mathrm{O}_{2}\right)$ the concentrations of $\mathrm{III}^{* *}$ and III* will significantly decrease, due to efficient quenching of III**, reaction (b), so reaction (e) will become less important.

Although the mechanism explains the observations reasonably well, it should be remembered that it is only based on the observed HONO yield. None of the other reaction products, e.g., the proposed ketene, ${ }^{23}$ were detected with the FTIR spectrometer. The mechanism is still highly speculative and needs to be validated by additional product and spectroscopic studies, and theoretical calculations.

In a recent study, ${ }^{63}$ the instantaneous formation of submicron particles was observed during the photolysis of nitrophenols. Based on the mechanism proposed in this study, the formation of particles from the photolysis of nitrophenols is not unexpected. For example, the proposed biradical, reaction (d) in mechanism (3), will most probably undergo further reactions such as isomerisation, leading to the formation of acids $^{23}$ or reactions with nitrophenols, probably generating higher molecular species with vapour pressures low enough to generate particles. Detailed product studies will be necessary in order to explain the observed formation of particles during the photolysis of nitrophenols.

Although in most experiments 3M2NP was used, the photolytically induced HONO formation from other nitrophenols was also investigated. Although not as efficient as 3M2NP, HONO formation was observed for all of the ortho-nitrophenol compounds investigated (see Table 1). Thus, it is to be expected that even higher molecular ortho-nitrophenols, such as nitro-PAH derivates and also polynitro-phenols and polyhydroxy-nitroaromatics will form HONO during photolysis. Using $a b$ initio and density functional theory a photoinduced hydrogen transfer leading to the nitronic acid structure III was also recently proposed for 2-nitrotoluene. ${ }^{64}$ Thus, it is possible that nitroaromatic compounds with even weaker hydrogen donors than the phenolic $\mathrm{OH}$ group in the ortho-position to the nitro group might form HONO during irradiation. This opens a field for further studies on photoinduced HONO formation from a wide variety of nitroaromatic hydrocarbons.

\section{Atmospheric implications}

For a rough estimate of the homogeneous HONO formation rate upon photolysis of ortho-nitrophenols in the atmosphere, a concentration of 1 ppbv for these compounds has been assumed, which is taken as being representative of urban conditions. Recently, gas phase mixing ratios of $\sim 60 \mathrm{pptv}$ of ortho-nitrophenol were measured at an urban site. ${ }^{11}$ Since photolytic HONO formation is expected for all phenolic aromatic hydrocarbons with a nitro group in an ortho-position to the $\mathrm{OH}$ group, including higher molecular nitro-PAHs, polynitro- and polyhydroxy-aromatics, a mixing ratio of 1 ppbv is considered reasonable for the total of all these compounds present in the urban troposphere. In addition, as speculated above, other classes of nitroaromatics might also form HONO upon photolysis.

Since a linear dependence of the HONO yield on the nitrophenol concentration was observed, the results obtained here have been extrapolated linearly to atmospheric concentrations. However, it should borne in mind that the experiments were performed in the ppmv range and thus the extrapolation to atmospheric conditions needs to be verified using more sensitive detection of the nitrophenols.

A linear dependence of the HONO yield on the light intensity (i.e., the number of lamps switched on) and on measured $J\left(\mathrm{NO}_{2}\right)$ was observed for a spectral range of 300-500 nm $\left(\lambda_{\max }=370 \mathrm{~nm}\right)$ within the reactor. Because the wavelength dependency of the process was not studied, a direct extrapolation of the results to atmospheric conditions is uncertain. However, since (i) the nitrophenols studied absorb in the spectral range of the lamps used, (ii) the $\mathrm{NO}_{2}$ photolysis is most efficient at wavelengths $<400 \mathrm{~nm}$, and (iii) the lower spectral limit of the lamps is comparable to atmospheric 
conditions, the measured ratio $J(3 \mathrm{M} 2 \mathrm{NP} \rightarrow \mathrm{HONO}) / J\left(\mathrm{NO}_{2}\right)$ was used to estimate the photolytic HONO formation under atmospheric conditions. Calculations using actinic flux spectra from the atmosphere indeed show that the ratio $J(3 \mathrm{M} 2 \mathrm{NP} \rightarrow$ $\mathrm{HONO} / J\left(\mathrm{NO}_{2}\right)$ is similar to the photo-reactor conditions and virtually independent of time if a wavelength independent HONO quantum yield is assumed.

Based on experimental data obtained for $3 \mathrm{M} 2 \mathrm{NP}$ and applying the assumptions described above, a photolytic HONO formation rate of 100 pptv $\mathrm{h}^{-1}$ is estimated for a maximum $J\left(\mathrm{NO}_{2}\right)$ value of $10^{-2} \mathrm{~s}^{-1}$ in the presence of $1 \mathrm{ppbv}$ of nitrophenols. Results obtained in recent field campaigns ${ }^{38,41-43}$ suggested the presence of an additional photolytic HONO source. In one study, ${ }^{43}$ the existence of a daytime source of HONO was unequivocally demonstrated based only on experimental observation. For semi-urban conditions, a daytime source of HONO of $500 \mathrm{pptv} \mathrm{h}^{-1}$ was calculated. Thus, the mechanism proposed in the present study might explain a significant fraction of the observed HONO formation in the urban atmosphere, besides other postulated photolytic HONO sources. ${ }^{38,47,49,52-54}$ However, this estimate needs to be verified using data from further experiments performed under atmospheric conditions, and also investigations on the wavelength dependencies of the photolysis processes.

\section{Acknowledgements}

The financial support for the development of the LOPAP instrument by the German Environment Foundation (DBU) under contract No. 12634 and the German Federal State of Northrhine Westphalia is gratefully acknowledged. The authors are also indebted to two anonymous referees for their helpful review.

\section{References}

1 J. Calvert, R. Atkinson, K. H. Becker, R. Kamens, J. Seinfeld, T. Wallington and G. Yarwood, in The Mechanisms of the Atmospheric Oxidation of Aromatic Hydrocarbons, Oxford University Press, New York, 2002.

2 R. Atkinson, Atmos. Environ., 2000, 34, 2063-2101.

3 R. Atkinson and J. Arey, Chem. Rev., 2003, 103, 4605-4638.

4 R. G. Derwent, M. E. Jenkin and S. M. Saunders, Atmos. Environ., 1996, 30, 181-199.

5 R. G. Derwent, M. E. Jenkin, S. M. Saunders and M. J. Pilling, Atmos. Environ., 1998, 32, 2429-2441.

6 J. R. Odum, T. Hoffmann, F. Bowman, D. Collins, R. C. Flagan and J. H. Seinfeld, Environ. Sci. Technol., 1996, 30, 2580-2585.

7 H. J. L. Forstner, R. C. Flagan and J. H. Seinfeld, Environ. Sci. Technol., 1997, 31, 1346-1358.

8 M. D. Hurley, O. Sokolov, T. J. Wallington, H. Takekawa, M. Karasawa, B. Klotz, I. Barnes and K. H. Becker, Environ. Sci. Technol., 2001, 35, 1358-1366.

9 G. Rippen, E. Zietz, R. Frank, T. Knacker and W. Klöpffer, Environ. Technol. Lett., 1987, 8, 475-482.

10 A. Kawai, S. Goto, Y. Matsumoto and H. Matsushita, Jap. J. Ind. Health, 1987, 29, 34-54.

11 M. A. J. Harrison, S. Barra, D. Borghesi, D. Vione, C. Arsene and R. I. Olariu, Atmos. Environ., 2005, 39, 231-248, and references therein.

12 R. Atkinson, S. Aschmann and J. Arey, Environ. Sci. Technol., 1992, 26, 1397-1403.

13 E. Bolzacchini, M. Bruschi, J. Hjorth, S. Meinardi, M. Orlandi, B. Rindone and E. Rosenbohm, Environ. Sci. Technol., 2001, 35, 1791-1797.
14 R. I. Olariu, B. Klotz, I. Barnes, K. H. Becker and R. Mocanu, Atmos. Environ., 2002, 36, 3685-3697.

15 D. Grosjean, Sci. Total Environ., 1991, 100, 367-414.

16 R. Belloli, B. Barletta, E. Bolzacchini, S. Meinardi, M. Orlandi and B. Rindone, J. Chromatogr., A, 1999, 846, 277-281.

17 J. Tremp, P. Mattrel, S. Fingler and W. Giger, Water, Air, Soil Pollut., 1993, 68, 113-123.

18 J. Lüttke and K. Levsen, Atmos. Environ., 1997, 31, 2649-2655.

19 Z. Voznakova, J. Podehradska and M. Kohlickova, Chemosphere, 1996, 33, 285-291.

20 R. Herterich, J. Chromatogr., 1991, 549, 313-324.

21 K. Kawamura and I. R. Kaplan, Atmos. Environ., 1986, 20, $115-124$.

22 M. I. O. Ishag and P. G. N. Moseley, Tetrahedron, 1977, 33, 3141-3144.

23 A. Alif, J.-F. Pilichowski and P. Boule, J. Photochem. Photobiol., A, 1991, 59, 209-219.

24 C. Bing, Y. Chun and G. N. Khang, J. Environ. Sci. (China), 2005, 17, 598-604.

25 Y. Dubowski and M. R. Hoffmann, Geophys. Res. Lett., 2000, 27, 3321-3324.

26 W. F. Baitinger, P. R. von Schleyer, T. S. S. R. Murty and L. Robinson, Tetrahedron, 1964, 20, 1635-1647.

27 S. Leavell and R. F. Curl Jr, J. Mol. Spectrosc., 1973, 45, 428-442.

28 V. M. Schreiber, J. Mol. Struct., 1989, 197, 73-85.

29 K. B. Borisenko, C. W. Bock and I. Hargittai, J. Phys. Chem., 1994, 98, 1442-1448.

30 K. B. Borisenko and I. Hargittai, J. Mol. Struct., 1996, 382, 171-176.

31 P. C. Chen, M. Lo and S. C. Tzeng, J. Mol. Struct. (THEOCHEM), 1998, 428, 257-266.

32 A. Kovács, V. Izvekov, G. Keresztury and G. Pongor, Chem. Phys., 1998, 238, 231-243.

33 A. Kovács, G. Keresztury and V. Izvekov, Chem. Phys., 2000, 253, 193-204

34 P. C. Chen and Y. C. Chieh, Chem. Phys. Lett., 2003, 372, $147-155$.

35 M. Polášek, F. Tureček, P. Gerbaux and R. Flammang, J. Phys. Chem. A, 2001, 105, 995-1010.

36 A. Neftel, A. Blatter, R. Hesterberg and Th. Staffelbach, Atmos. Environ., 1996, 30, 3017-3025.

37 T. Staffelbach, A. Neftel and L. W. Horowitz, J. Geophys. Res., 1997, 102, 23363-23373.

38 X. Zhou, K. Civerolo, H. Dai, G. Huang, J. Schwab and K. Demerjian, J. Geophys. Res., 2002, 107, 4590, DOI: 10.1029/ 2001JD001539.

39 B. Alicke, U. Platt and J. Stutz, J. Geophys. Res., 2002, 107, 8196, DOI: $10.1029 / 2000 J D 000075$.

40 B. Alicke, A. Geyer, A. Hofzumahaus, F. Holland, S. Konrad, H. W. Pätz, J. Schäfer, J. Stutz, A. Volz-Thomas and U. Platt, J. Geophys. Res., 2003, 108, 8247, DOI: 10.1029/2001 JD000579.

41 J. Kleffmann, R. Kurtenbach, J. C. Lörzer, P. Wiesen, N. Kalthoff, B. Vogel and H. Vogel, Atmos. Environ., 2003, 37, 2949-2955.

42 B. Vogel, H. Vogel, J. Kleffmann and R. Kurtenbach, Atmos. Environ., 2003, 37, 2957-2966.

43 J. Kleffmann, T. Gavriloaiei, A. Hofzumahaus, F. Holland, R. Koppmann, L. Rupp, E. Schlosser, M. Siese and A. Wahner, Geophys. Res. Lett., 2005, 32, L05818, DOI: 10.1029/ 2005 GL022524.

44 L. Gutzwiller, F. Arens, U. Baltensperger, H. W. Gäggeler and M. Ammann, Environ. Sci. Technol., 2002, 36, 677-682.

45 B. J. Finlayson-Pitts, L. M. Wingen, A. L. Sumner, D. Syomin and K. A. Ramazan, Phys. Chem. Chem. Phys., 2003, 5, 223-242.

46 M. Ammann, E. Rössler, R. Strekowski and C. George, Phys. Chem. Chem. Phys., 2005, 7, 2513-2518.

47 X. Zhou, H. J. Beine, R. E. Honrath, J. D. Fuentes, W. Simpson, P. B. Shepson and J. W. Bottenheim, Geophys. Res. Lett., 2001, 28, 4087-4090.

48 X. Ren, H. Harder, M. Martinez, R. L. Lesher, A. Oliger, J. B. Simpas, W. H. Brune, J. J. Schwab, K. L. Demerjian, Y. He, X. Zhou and H. Gao, Atmos. Environ., 2003, 37, 3639-3651.

49 X. Zhou, Y. He, G. Huang, T. D. Thornberry, M. A. Carroll and S. B. Bertman, Geophys. Res. Lett., 2002, 29(14), 1681, DOI: 10.1029/2002GL015080. 
50 X. Zhou, H. Gao, Y. He, G. Huang, S. B. Bertman, K. Civerolo and J. Schwab, Geophys. Res. Lett., 2003, 30(23), 2217, DOI: 10.1029/2003GL018620.

51 K. A. Ramazan, D. Syomin and B. J. Finlayson-Pitts, Phys. Chem. Chem. Phys., 2004, 6, 3836-3843.

52 C. George, R. S. Strekowski, J. Kleffmann, K. Stemmler and M. Ammann, Faraday Discuss., 2005, 130, 1-16, doi:10.1039/ b417888m.

53 K. Stemmler, M. Ammann, J. Kleffmann and C. George, Geophysical Research Abstracts, 2005, 7, 07661, SRef-ID: 1607-7962/gra/ EGU05-A-07661, European Geosciences Union.

54 K. Stemmler, M. Ammann, J. Kleffmann and C. George, Nature, 2006, 440(7081), 195-198.

55 A. Hofzumahaus, A. Kraus and M. Müller, Appl. Opt., 1999, 38, 4443-4460.

56 J. Heland, J. Kleffmann, R. Kurtenbach and P. Wiesen, Environ. Sci. Technol., 2001, 35, 3207-3212.

57 J. Kleffmann, J. Heland, R. Kurtenbach, J. C. Lörzer and P. Wiesen, Environ. Sci. Pollut. Res., 2002, 9(special issue 4), $48-54$.
58 L. Gutzwiller, F. Arens, U. Baltensperger, H. W. Gäggeler and M. Ammann, Environ. Sci. Technol., 2002, 36, 677-682.

59 J. Kleffmann, J. C. Lörzer, P. Wiesen, S. Trick, R. Volkamer, M. Rodenas and K. Wirtz, Atmos. Environ., 2005, accepted for publication.

60 R. I. Olariu, PhD Thesis, University of Wuppertal, Germany, 2001.

61 B. J. Finlayson-Pitts and J. N. Pitts Jr, Chemistry of the Upper and Lower Stratosphere, Academic Press, San Diego, 2000.

62 R. Atkinson, D. L. Baulch, R. A. Cox, J. N. Crowley, R. F. Hampson Jr, R. G. Hynes, M. E. Jenkin, J. A. Kerr, M. J. Rossi and J. Troe, in Summary of Evaluated Kinetic and Photochemical Data for Atmospheric Chemistry, IUPAC Subcommittee on Gas Kinetics Data Evaluation for Atmospheric Chemistry, Web Version, www.iupac-kinetic.ch.cam.ac.uk, University of Cambridge, UK, 2005.

63 I. G. Bejan, I. Barnes, R. Olariu and R. Mocanu, Geophysical Research Abstracts, 2004, 6, 07566, SRef-ID: 1607-7962/gra/ EGU04-A-07566, European Geosciences Union.

64 Y. V. Il'ichev and J. Wirz, J. Phys. Chem. A, 2000, 104, 7856-7870. 